\title{
Foraging behavior of two egg parasitoids exploiting chemical cues from the stink bug Piezodorus guildinii (Hemiptera: Pentatomidae)
}

\author{
MARÍA FERNANDA CINGOLANI ${ }^{1}$, MARÍA C. BARAKAT ${ }^{1}$, GERARDO \\ GUSTAVO LILJESTHRÖM ${ }^{1}$ and STEFANO COLAZZA ${ }^{2}$ \\ ${ }^{1}$ Centro de Estudios Parasitológicos y de Vectores/CEPAVE/CONICET - FCNyM, \\ UNLP, Boulevard 120, s/n, La Plata (1900), Argentina \\ ${ }^{2}$ Universita degli Studi di Palermo, Dipartimento di Scienze Agrarie, Alimentari e \\ Forestali, Palermo, Viale delle Scienze, 90128 Palermo, Italy \\ Manuscript received on June 12, 2018; accepted for publication on October 2, 2018
}

\begin{abstract}
How to cite: CINGOLANI MF, BARAKAT MC, LILJESTHRÖM GG AND COLAZZA S. 2019. Foraging behavior of two egg parasitoids exploiting chemical cues from the stink bug Piezodorus guildinii (Hemiptera: Pentatomidae). An Acad Bras Cienc 91: e20180597. DOI. 10.1590/0001-3765201920180597.

Abstract: Several parasitoids attacking the same host may lead to competition. Adult parasitoids' abilities to find, parasitize and defend hosts determine resource's retention potential. In soybean, two egg parasitoid species, Telenomus podisi and Trissolcus urichi (Hymenoptera: Platygastridae), compete on the egg masses of Piezodorus guildinii (Hemiptera: Pentatomidae) one of the major pest of this crop. We evaluated parasitoid's abilities to exploit hosts' footprints; and parasitoid's behavior when competing for the same host. Both arena residence time and retention time were similar for T. podisi and T. urichi on male or female host footprints. In its turn, $T$. urichi reentered the area contaminated with P. guildinii more times and staid longer in it than T. podisi. Furthermore, when competing for the same egg mass, each parasitoid species won (was in possession of the host by the end of the experiment) half of the replicates, and the number of times each wasp species contacted host in the first place was similar, without affecting replicate outcome (who ultimately won). Both species started agonistic and non-agonistic encounters. This study provides information about the potential interspecific competition between these parasitoids, which contributes to evaluate the compatibility of multiple natural enemies' biological control programs for stink bugs.
\end{abstract}

Key words: biological control, coexistence, natural enemies, Platygastridae, searching behavior, stink bugs.

\section{INTRODUCTION}

Competition is an interaction that occurs among two or more individuals of the same or different species (intraspecific or interspecific, respectively), which arises when the supply of a scarce resource does not satisfy the immediate needs of individuals.

Correspondence to: María Fernanda Cingolani

E-mail: fernandacingolani@cepave.edu.ar

ORCid: https://orcid.org/0000-0002-2838-4590
Insect parasitoids have a very specialized life cycle that includes an immature stage that develops on or within a single host, ultimately killing that host. Therefore, competition is considered a more important phenomenon in solitary parasitoids than at other trophic levels, since individual hosts constitute a small resource sufficient for only one parasitoid (Godfray et al. 1994). In nature, a single host species can have multiple parasitoid species, which often results in intense interactive 
competition for the host resource (Cusumano et al. 2016). Competition can occur between adult parasitoids (extrinsic competition), i.e. interactions between females searching for or exploiting hosts, as well as between immature parasitoids (intrinsic competition), i.e. between larvae developing in the same host (Zwölfer 1971). Zwölfer (1971) classified parasitoids as "extrinsically superior" if they have better skills in host location and "intrinsically superior" if they have better skills in larval competition. He argued that the superior dispersal capabilities of poorer intrinsic competitors are important in explaining coexistence (Fugitive species hypothesis).

In extrinsic competition, a parasitoids' ability to find a host, to parasitize it and to defend it determine the potential for retention of parasitoid's resource (Cusumano et al. 2016). Female parasitoids searching for hosts find and explore a variety of stimuli, among which chemical cues (semiochemical) play an important role (Conti and Colazza 2012, Fatouros et al. 2016). These cues may originate directly from the host or from their products such as faeces, silk, or exuviae. Additionally, they may be emitted from the food plants of hosts (Steidle and van Loon 2003). Cues not produced directly from the host may be originated far from the exact location of it. The localization and recognition of suitable hosts is a complex process, especially in oophagous parasitoids, since eggs are generally available for a short period of time given their rapid development. As semiochemicals coming from egg masses may be undetectable, oophagous parasitoids have developed specialized searching strategies. Several species of hymenopteran oophagous parasitoids from the family Platygastridae use footprints left by adults and/or juveniles of their hosts, and the typical response to these cues is a retention behavior (the parasitoid remains in the vicinity) (Colazza et al. 2014). The ability to discriminate semiochemicals originated from gravid females could ensure parasitoids location of newly laid eggs.

Pentatomids are the main soybean seed sucking pests. From them, Piezodorus guildinii (Westood) (Hemiptera: Pentatomidae) is the most important species in Argentina (Gamundi and Sosa 2008). It is also one of the most relevant stink bugs in Brazil (Corrêa-Ferreira 2008), Uruguay (Castiglioni et al. 2008) and several states of the United States (Temple et al. 2013). From the whole complex of soybean stink bugs, $P$. guildinii provokes the deepest seed damage (Depieri and Panizzi 2011) and causes greater leaf retention causing problems in the harvesting process (Corrêa-Ferreira and Azevedo 2002). Moreover, P. guildinii is highly mobile and more difficult to control with insecticides (Temple 2011). Adults are not attacked by parasitoids (Liljesthröm and Avalos 2015), as happens with the other stink bug species in the complex, what represents an empty niche. Egg parasitoids are important natural enemies that limit stink bug numerical increase. These parasitoids are considered "quasi-gregarious" due to the oviposition habits of their hosts, who lay their eggs in patches (egg masses). Concerning P. guildinii egg parasitoids, in the Neotropical region the most common species are Telenomus podisi (Ashmead) and Trissolcus urichi (Crawford) (Hymenoptera: Platygastridae).

Evidences of competition among different parasitoids species have been documented from host egg masses parasitized in field from which two or more different parasitoids species have emerged from individual eggs (Cusumano et al. 2011). For example, T. podisi and T. urichi or Trissolcus basalis Wollaston (Hymenoptera: Pentatomidae) emerged together from different eggs of the same $P$. guildinii egg mass (Cingolani et al. 2014a).

Cingolani et al. (2013) found that neither $T$. podisi nor $T$. urichi avoided multiparasitism when in indirect (exploitative) competition, however, the outcome of multiparasitism was less favorable 
for T. podisi irrespective of whether it was the first or second to parasitize. The number of $T$. podisi adults emerging was significantly lower than for T. urichi. Furthermore, the proportion of T. podisi emerging from multiparasitized eggs was lower than the proportion emerging from eggs parasitized by this species only. Therefore, T. urichi seems to be a better intrinsic competitor and potentially able to exclude T. podisi. In the field, however, T. podisi was always the dominant species on $P$. guildinii egg masses whereas T. urichi was recorded only when host abundance was high (Cingolani et al. 2014a).

Several authors have investigated the performance of platygastrids on different hosts under laboratory conditions (Powell and Shepard 1982, Liljesthröm and Cameán 1992, CorrêaFerreira 1993, Colazza and Bin 1995, Pacheco and Corrêa-Ferreira 1998, Kivan and Kiliç 2002, Sujii et al. 2002), although very few have evaluated $P$. guildinii as a host (Cingolani et al. 2014b).

Understanding how interspecific competition between parasitoids can affect pest suppression may help to improve biological control. Research in this area has focused mainly on intrinsic competition while it is largely unexplored how extrinsic competition can affect biological control (Cusumano et al. 2012a). Although it is relatively straightforward to determine intrinsic competitive superiority by examining the outcome of multiparasitism, it is far harder to demonstrate extrinsic competitive superiority. Experimental studies of comparative host location are needed to assess extrinsic competitive superiority (Cusumano et al. 2012a). Regarding species of our study, the coexistence of T. urichi and T. podisi in soybean fields could be favored by compensation of skills in larval competition and host location efficiency of both parasitoid species. The specific objectives of our work were: 1) to evaluate the comparative abilities of T. podisi and T. urichi to locate and pursuit footprints left by male and female $P$. guildinii; 2) to evaluate T. podisi and T. urichi behavior when exploiting $P$. guildinii egg masses.

\section{MATERIALS AND METHODS}

\section{INSECT COLONIES}

We established stink bug and wasp cultures from individuals collected in Argentinean soybean fields during the 2015-2016 crop growing season. Adults of $P$. guildinii were kept in plastic cages $20 \times 20 \times 20$ $\mathrm{cm}$ with a ventilation window under laboratory conditions $\left(25 \pm 1^{\circ} \mathrm{C} ; 70 \pm 10 \% \mathrm{RH}\right)$. We provided fresh Phaseolus vulgaris (L.) (Fabales: Fabaceae) pods twice a week for feeding. Eggs were collected daily and preserved under the same conditions, for stink bugs and wasps colonies maintenance. Parasitoids (T. podisi and T. urichi) were reared on eggs of this stink bug and honey was provided daily as food source for adults.

The day before wasp females were used in experiments, they were isolated from the colony and placed in test tubes with honey. Female wasps were naïve to oviposition experience and host chemicals, were mated, and were 2-4 days old when used in trials. Wasps were allowed to acclimate in the experiment room $3 \mathrm{~h}$ before bioassays. Tests were conducted from 9:00 am to 1:00 pm in an isolated room under laboratory conditions.

We performed two different experiments: (1) we exposed parasitoids to chemical cues not directly associated with the presence of host eggs (host traces bioassays), and (2) we exposed parasitoids directly to a host egg mass (host egg masses bioassays).

\section{HOST TRACES BIOASSAYS}

Parasitoids' response to adult host footprints was investigated in an open arena consisting of a square sheet of filter paper $(25 \times 25 \mathrm{~cm})$. In the center of the arena, a circular area (6 cm diameter) was demarcated in the underside of the filter paper using a pencil, and this area was exposed for 30 
min to the stimuli, leaving the surrounding area of the arena untreated. The demarcation of the circular area was visualized by translucency. Each arena was used for testing only one wasp female. The stimuli (treatments) were: (1) footprints left by $P$. guildinii males, (2) footprints left by $P$. guildinii mated females in preoviposition state, (3) and a negative control, i.e. the same arena but without stink bug's footprints. For treatments 1 and 2, the exposition to stimuli was performed by keeping an adult of stink bug walking on the filter paper and let it to move continuously and uniformly in the constrained area. To ensure a constant contact of the bug legs onto the filter paper and, at the same time, to avoid contamination of the surface of the filter paper with possible bug volatiles, adults were constrained under a steel mesh cover, following Peri et al. (2006) methodology. Open arenas contaminated by bug's feces were not used for bioassays. Telenomus podisi and T. urichi female wasps were tested singly by gentle release in the middle of the circular area, and each wasp was tested only once. We performed 30 replicates for each treatment. Parasitoid behavior was visually observed until wasps flew away from or walked off the whole arena (the filter paper). We registered the time spent by wasps in each part of the arena (i.e. inside and outside the central circular area) using a stopwatch, and the number of times the wasp reentered this circular area (in case she had previously abandoned it).

Wasps' behavior was evaluated in terms of: (1) arena residence time, quantified over the entire arena pooling times spent by wasps in both inside and outside the central circular area, (2) retention time, i.e. the time spent by wasps inside the central circular area, (3) number of times each wasp reentered the central circular area.

Arena residence time was analyzed with a Kruskal-Wallis test. The proportion of the replicate total time that each wasp spent inside the central area was also compared with a Kruskal-Wallis test.
In all cases, comparisons of the average ranks for each pair of combinations were made computing normal z-values, as well as post hoc probabilities for a two sided test of significance (Zar 1996). We also compared residence time, inside ("retention time") or outside the treated area by evaluating Kaplan-Meier estimators and different KaplanMeier curves were compared by the log rank test. Additionally, the proportion of replicates in which each wasp reentered the central circular area was statistically compared with a Fisher exact test.

\section{HOST EGG MASSES BIOASSAY}

We studied behavioral interspecific interactions between adult platygastrids when searching for hosts simultaneously. One T. podisi and one T. urichi female wasp were released at the same moment into a small Petri dish (5 $\mathrm{cm}$ in diameter) containing an average host egg mass (15 eggs/egg mass). Eggs were less than $24 \mathrm{~h}$ old (the preferred development stage of the host, for these oophagous parasitoids), and were added to the arena using forceps. Behaviors of both females were observed for $2 \mathrm{~h}$, and two types of encounters between females were distinguished. The first type was non-agonistic encounters, in which females either physically contacted one another or came into extremely close proximity but exhibited no aggression. The second type was agonistic encounters, pooling both backdowns (one individual attacking and the other retreating without retaliation) and escalated fights (one individual attacking and the other retaliating and initiating a bout of mutual aggression). The female that possessed the host by the end of the experiment was assumed as the winner, whether there have been direct interactions between wasps or not during the observation period. We performed 22 replicates, and individual females and host egg masses were used in experiments only once.

We analyzed the proportion of replicates in which each wasp species won the host egg mass 
performing a Fisher exact test. We also analyzed the proportion of replicates in which each wasp species was the first one in contacting the host egg mass performing a Fisher exact test, and analyzed the effect of being the first or the second in contacting the egg mass, on replicate's outcome (who ultimately won or lost the egg mass) with a contingency table. Finally, we analyzed the number of agonistic and of non-agonistic encounters between $T$. podisi and T. urichi females searching for a host egg mass with ANOVA. Analyzes were performed using R software (R Core Team 2014).

\section{RESULTS}

\section{HOST TRACES BIOASSAYS}

When analyzing the arena residence time (time spent by wasps in the entire arena) wasps that were exposed to control treatment remained significantly less time on the arena than wasps exposed to host traces, regardless wasp species or host gender. On average, both $T$. podisi and $T$. urichi staid just about half a minute exploiting the arena in the control treatment before leaving $\left(\mathrm{H}_{(5 ; \mathrm{N}=180)}=114.622\right.$; $\mathrm{p}<0.001)$. Nonetheless, we removed control treatment from analysis and there were no differences in the arena residence time of T. podisi and $T$. urichi towards stink bug traces generated by female or male hosts $\left(\mathrm{H}_{(3 ; \mathrm{N}=120)}=6.206 ; \mathrm{p}<0.102\right)$ (Figure 1).

When comparing wasps' retention time (time spent by wasps inside the central circular area), both wasp species spent less time on areas without host traces (control) than on areas contaminated with host footprints $\left(\chi^{2}=125.27 ; \mathrm{df}=5 ; \mathrm{p}<0.001\right)$. However, we did not found differences in T. podisi or $T$. urichi retention time towards female or male hosts traces $\left(\chi^{2}=1.93 ; \mathrm{df}=3 ; \mathrm{p}=0.586\right)$ when analysis was made without considering data from control treatment (Table I).

When comparing time spent by wasps outside the central circular area, both wasp species spent

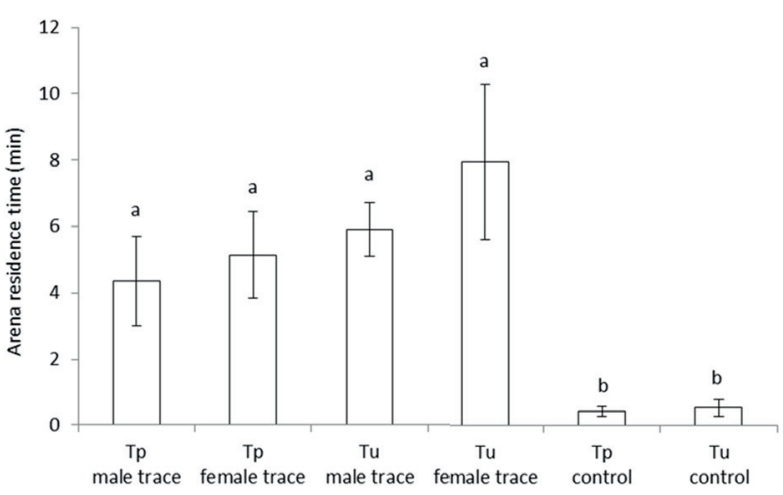

Figure 1 - Arena residence time (average time spent by wasps in the entire arena) when exploiting traces from Piezodorus guildinii female or male, or no stink bug traces (control). Different letters indicate significant differences. Bars denote 95\% confidence intervals. Tp: Telenomus podisi; Tu: Trissolcus urichi.

less time in control treatment than in male or female host traces treatments $\left(\chi^{2}=116.051 ; \mathrm{df}=5\right.$; $\mathrm{p}<0.001)$. Moreover, when we removed control treatment from analysis, we found differences between wasp species $\left(\chi^{2}=17.2 ; \mathrm{df}=3 ; \mathrm{p}<0.001\right)$, denoting that the risk of T. urichi abandoning the not treated area doubles the risk of $T$. podisi abandoning it $(\mathrm{p}<0.001)$.

From total replicate duration, T. urichi spent a higher proportion of time inside the central area treated with stink bug footprints (in average, 0.857 on male host traces and 0.845 on female host traces), and just a little proportion of time outside the central area where there were no host footprints. On the contrary, T. podisi spent a similar proportion of time inside the central area treated with female or male hosts (in average, 0.575 on female host traces and 0.479 on male host traces), and outside it. The same situation was seen in wasps from both species exposed to control treatment. The proportion of time of total replicate duration that T. urichi invested in exploiting stink bug's traces was significantly higher than the proportion of time invested by $T$. podisi on the circular treated area and the time invested by both wasp species on the 
TABLE I

Average time $(\min \pm \mathrm{SD})$ spent by parasitoid wasps $(T$. podisi and $T$. urichi) inside and outside the central circular area, treated with $q$ or $\curvearrowright$ P. guildinii (host) traces, or not exposed to host traces (control).

\begin{tabular}{|c|c|c|c|c|c|c|}
\hline & \multicolumn{2}{|l|}{ Control } & \multicolumn{4}{|c|}{ Host traces } \\
\hline & \multirow[b]{2}{*}{ inside } & \multirow[b]{2}{*}{ outside } & \multicolumn{2}{|r|}{ 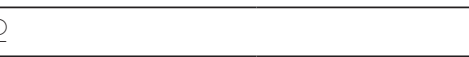 } & \multicolumn{2}{|c|}{3} \\
\hline & & & inside & outside & inside & outside \\
\hline T. podisi & $0.189 \pm 0.158^{\mathrm{B}}$ & $0.237 \pm 0.363^{c}$ & $3.593 \pm 3.523^{\mathrm{A}}$ & $1.552 \pm 1.296^{\mathrm{a}}$ & $2.648 \pm 3.491^{\mathrm{A}}$ & $1.712 \pm 2.340^{\mathrm{a}}$ \\
\hline T. urichi & $0.371 \pm 0.590^{\mathrm{B}}$ & $0.177 \pm 0.210^{c}$ & $5.675 \pm 1.786^{\mathrm{A}}$ & $1.157 \pm 0.932^{b}$ & $5.179 \pm 2.123^{A}$ & $0.747 \pm 0.484^{b}$ \\
\hline
\end{tabular}

Different letters indicate significant differences in time spent by wasps inside (uppercase) or outside (lowercase) the central circular area, among treatments.

central area in control treatments $\left(\mathrm{H}_{(5 ; \mathrm{N}=180)}=34.264\right.$; $\mathrm{p}<0.001)$.

When analyzing the number of times $T$. podisi and T. urichi reentered the central circular area, we found that on control treatments wasps almost never reentered the central area after leaving (it happened only in 2 out of 30 replicates from $T$. urichi). From treatments where the central circular area was exposed to stink bugs' footprints, T. podisi usually reentered the treated area less often than T. urichi. Telenomus podisi reentered the area treated with male host's traces only in 8 of the 30 replicates, and in the remaining 22 replicates the wasps abandoned the whole arena upon leaving the treated area and never returned. On the contrary, T. urichi abandoned the treated area and then reentered it in almost all the 30 replicates (29 out of 30), in fact reentering numerous times in each replicate. Similar results were found when wasps exploited female host traces (T. podisi reentered in 12 out of 30 replicates; T. urichi reentered in 29 out of 30 replicates). The proportion of times T. urichi reentered the area contaminated with female or male $P$. guildinii was higher than the proportion for $T$. podisi reentering area contaminated with female (Fisher exact test $\mathrm{p}<0.001$ ) or male hosts (Fisher exact test $\mathrm{p}<0.001)$. On average, $T$. podisi reentered the central area with stink bug's footprints 1.5 times per replicate, both for male or female traces. In contrast, T. urichi exploited host traces more insistently, reentering on average 4.43 and 5.47 times per replicate from male and female traces, respectively.

\section{HOST EGG MASSES BIOASSAY}

Each parasitoid species won about half of the replicates (T. podisi won 8 times; T. urichi won 12 times; 2 of the replicates ended tied) (Fisher exact test $p=0.214$ ). The number of times wasps from either species contacted the host egg mass in the first place was similar (T. podisi: $12 ;$ T. urichi: 10) (Fisher exact test $\mathrm{p}=0.554$ ), and it did not affect replicate resolution $\left(\chi^{2}=0.952 ; \mathrm{df}=1 ; \mathrm{p}=0.329\right)$ as T. podisi won 6 times being the first who have contacted the egg mass, and T. urichi won 8 times being the first who have contacted the egg mass. In four of the replicates $T$. podisi was the species who contacted the egg mass first but she was displaced by a female of $T$. urichi out from the egg mass, forcing T. podisi to lose the host. A similar situation occurred in two of the replicate where T. urichi was first to contact the egg mass but $T$. podisi finally won the host.

Both parasitoid species started non-agonistic encounters in a similar number of times $(\mathrm{F}=0.536$; $\mathrm{df}=1 ; \mathrm{p}=0.468$ ) (Figure 2). When encountering a heterospecific competitor during host exploitation, T. posidi and T. urichi females displayed agonistic behaviors. The repertoire of agonistic behaviors consisted of chasing and hitting, behaviors that led to the departure of one of the females (the loser) from the host egg mass. The number of times each species started agonistic encounters was also 


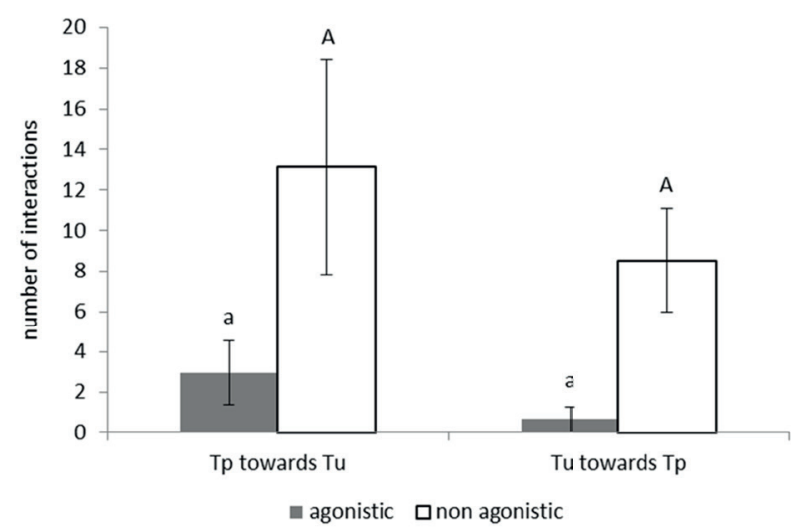

Figure 2 - Mean agonistic and non-agonistic encounters per trial between Telenomus podisi (Tp) and Trissolcus urichi (Tu) when searching simultaneously for Piezodorus guildinii egg masses. Different letters indicate significant differences in the number of agonistic (small letters) or non-agonistic (capital letters) encounters between wasps. Bars denote 95\% confidence intervals.

similar for T. podisi and T. urichi $(\mathrm{F}=1.593 ; \mathrm{df}=2$; $\mathrm{p}=0.214$ ) (Figure 2). Thereby, T. podisi seemed to be more aggressive than $T$. urichi, attacking more insistently. During all of these observations no females were killed, but if well injuries were rare, in two cases T. urichi females ended with the distal segment of two or three of their legs bitten off. In any case, this did not appear to impair the female's ability to continue searching for the host.

\section{DISCUSSION}

We found that T. urichi was more insistent than T. podisi when exploiting $P$. guildinii footprints, searching more actively and spending significantly more time on host traces. These results demonstrate some difference in the relative response of parasitoid species to kairomones, which can affect the success of the parasitoid that exploits hosts'cues while searching for eggs.

Lo Giudice et al. (2010) demonstrated the importance of plant surfaces in mediating interactions between chemical footprints of hosts and their egg parasitoids. They found that epicuticular waxes of leaves of broad bean, Vicia faba L. (Fabales: Fabaceae) and collard greens,
Brassica oleracea L. (Brassicales: Brassicaceae), mediate the foraging behavior of T. basalis by adsorbing contact kairomones from adults of Nezara viridula L. (Hemiptera: Pentatomidae). Although the experimental units we used for the trials are rather artificial in representing natural conditions found by wasps in field, both wasp species only remained a very short period of time searching on the control treatment. That may indicate that filter paper absorbed properly the contact kairomones from $P$. guildinii.

In field conditions, to find hosts, egg parasitoid females can exploit semiochemicals arising from the host eggs, from the interaction of the plant and the eggs, or from stages other than the one attacked (Powell and Wright 1992, Fatouros et al. 2008). This last group of semiochemicals (indirect host-related cues) brings female wasps in proximity to potential host eggs but does not provide information on the location of host eggs itself. When in contact with an area contaminated with semiochemicals wasps show an arrestment response (i.e. a motionless period with the antennae kept in contact with the surface) followed by an intense searching behavior characterized by variation in orthokinesis and klinokinesis, and increased turning frequency (Conti et al. 2004). If no host eggs are found, wasps resume the normal walking pattern, abandoning the contaminated area.

Colazza et al. (1999) and Peri et al. (2011) found that $T$. basalis is able to exploit volatile oviposition-induced synomones, volatiles cues from virgin males and preovipositing females, and contact kairomones in the host footprints, while Ooencyrtus telenomicida (Vassiliev) (Hymenoptera: Encyrtidae) seems to use volatiles from host virgin males and from host mated females in preovipositional state. They argue that this diversity in terms of the nature of cues exploited may explain the superior host finding abilities of $T$. basalis, evidenced by higher $T$. basalis parasitization rate recorded in the field. 
Concerning species of our work, numerous studies have suggested that several compounds could influence the behavior of T. podisi (Borges et al. 1999, 2003, Blassioli Moraes et al. 2005, 2009) but little is known about the diversity of cues that $T$. urichi can exploit during host finding process.

It was demonstrated that several platygastrid species only discriminates between footprints left by females or male host, when traces were left by their associated hosts (Colazza et al. 1999, 2007, Conti et al. 2004, Salerno et al. 2009, Peri et al. 2013). Peri et al. (2013) evaluated the ability of three platygastrid egg parasitoid species to detect adult host sex on the basis of the host traces left by three pentatomid species on filter paper. They found that wasps discriminated between chemical traces left by a pentatomid female versus male, exhibiting a clear preference for female traces only when these belonged to their associated hosts. No significant differences were observed when wasps were in contact with footprints of non-associated species. The two wasp species evaluated in our study showed high parasitism proportions when $P$. guildinii eggs were offered as hosts in laboratory assays (Cingolani et al. 2014b). However $P$. guildinii may not be the chosen host if the wasps are allowed to choose among different pentatomid species eggs. The response of T. podisi and T. urichi to host sex traces may indicate that $P$. guildinii is not the preferred host for these parasitoid species.

Another possible explanation for our results could be a differential use of infochemicals by T. podisi and T. urichi in relation to their dietary specialization. According to this concept, the more specialized a parasitoid is, the more information it needs to know for locating a host. Therefore, egg parasitoid species with a narrow host range should exploit specific cues more frequently than generalist species. Generalists need to invest less time in searching particular host species than specialists. Therefore, the use of infochemicals in order to reduce searching time is less important.
When comparing T. podisi and T. urichi dietary specialization, the former is a generalist parasitoid that was reported from more than 20 different host species, but $T$. urichi is a more specialized parasitoid reported from only 10 different host species (Rider 2015). Additionally, as suggested by Margaría (2008), the Telenomini tribe is under adaptive radiation, so this process could be influencing wasps' behaviors and their host's preferences in the field. In our study, T. urichi dedicated a higher proportion of time to exploit host traces than $T$. podisi. This could indicate a differential use of infochemicals in relation of differences in these species' dietary specializations, and may be an explanation for the prevalence of $T$. podisi on field collected P. guildinii eggs (Cingolani et al. 2014a). Theory suggests that specialist species are more competitive in their optimal habitats. However, empirical work has shown that specialist species are declining worldwide due to habitat loss and fragmentation (Büchi and Vuilleumier 2014). This could be the case of these two parasitoid species that exploit a common host, T. urichi being more competitive in laboratory assays but $T$. podisi being more competitive in natural communities.

The females of a lot of parasitoid insect species are time limited, unable to find enough hosts in which to lay all their eggs in one searching period. Time spent searching a patch on which there are few suitable hosts could be considered wasteful, so that allocation of time spent searching a patch becomes an important factor in the reproductive success of a parasitoid female (Nelson and Roitberg 1995). Optimal foraging theory (Stephens and Krebs 1986) assumes that animals adjust their behavior to maximize their lifetime reproductive success under different ecological conditions. The resources used by female insect parasitoids are hosts that can be dispersed in the habitat or aggregated in patches, and whose value varies, for example, according to the host species, among other characteristics. How long, and therefore to what 
limits, patches should be exploited is one of the key factors determining the foraging success of female parasitoids and is therefore a central question in the behavioral ecology of insect parasitoids. In this sense, Peri et al. (2006) indicated that females of T. basalis and Trissolcus brochymenae (Ashmead) (Hymenoptera: Platygastridae) are able to learn the features of their foraging environment and to adjust accordingly the amount of time spent on the patches of kairomones they are visiting, depending on whether or not host eggs are found. Leaving earlier a patch containing indirect indicators of host presence, as semiochemicals originated from male hosts, enables parasitoids to forage another patch and therefore to increase parasitoid's opportunity to find host eggs.

When we exposed parasitoids directly to a host egg mass, we found no differences in T. podisi and T. urichi abilities to find and take possession of host eggs. Our experiments did not assess the effect of some characteristics that can influence the ease with which wasps find their hosts in the field, such as differences in dispersal abilities, host preference, learning abilities, etc., since we performed tests in small Petri dishes and we used young, naïve and fed wasps. This kind of experiments may provide some information about potential behavior of wasps, but more complicated semifield experiments should be performed to evidence differential host finding abilities between species.

Frequently, after one wasp species had oviposited, a female of the other species took over and started parasitizing another host egg without disturbing each other. In other cases, when encountering a heterospecific during host exploitation, both T. podisi and T. urichi females displayed agonistic behaviors, from non-aggressive contacts to full attacks, towards their opponent. Although both species committed a similar number of aggressive encounters one against the other, we observed that the intensity of this encounters were somewhat unbalanced. Telenomus podisi seemed to be always more aggressive than T. urichi. Moreover, even only few escalations led to serious injuries, the perpetrator was always $T$. podisi. This is an observation we made while performing the experiments, however, we did not quantify this aggressiveness in order to search for statistically significant differences. We just counted the number of agonistic encounters without giving a dimension to the aggression.

If well we did not analyze the resultant outcome in terms of offspring production, which is most strongly linked to fitness, in most cases the emerged wasps were all of the species who had had greater possession of the egg mass. In only five of the replicates we registered emergence of wasps of both species from one egg mass, although in those cases the proportion of emerged T. urichi individuals was always greater than the proportion of $T$. podisi emerged individuals. This may be because of multiparasitism of some of the eggs of the egg mass, and to the known supremacy of $T$. urichi in the intrinsic competition (Cingolani et al. 2013).

Aggressive host and brood guarding behaviors have been documented for many other platygastrids species. For example, Field and Calbert (1999) reported that intruder-owner contests for hostpatches in female $T$. basalis rarely result in escalation: more frequently, the owner attacks and the intruder retreats. While the majority of works concern intraspecific interactions (Field 1998, Field and Calbert 1998, Field et al. 1998), behavioral defense against allospecifics is also reported (Cusumano et al. 2012b, 2013, Peri et al. 2014).

Although we did not quantified how injurious and/or potentially fatal encounters were, examination of interspefic interactions revealed that while agonistic contests often occur, fatalities do not. Game-theoretic models predict that both contestants benefit from avoidance of injurious or fatal fighting when the contested resource has 
lesser value to contestants than resources expected to be found in the future, in which case contests are likely to be settled by non-injurious mechanisms such as convention or display (Maynard Smith and Parker 1976, Enquist and Leimar 1990). Fights resulting in injury or death are only expected when the value of the contested resource is similar to or greater than the expected value of future resources (Enquist and Leimar 1990). In animal contests, theoretical studies using game theory modeling and the concept of evolutionarily stable strategies (Maynard Smith 1974) suggest that the competitive abilities of competitors are defined in terms of their resource-holding potential (i.e. difference in the abilities of the contestants to acquire and retain resources) (Maynard Smith and Parker 1976, Hammerstein 1981), with the contested resource not necessarily being of equal value to each competitor (Hughes 1979, Goubault et al. 2007). First-arriving individuals usually place a higher value on the resource and contests are predicted to be won by the contestant with the highest resourceholding potential and/or resource value (Enquist and Leimar 1987, Parker 1974). Even thought we did not vary the conditions influencing the outcomes of contests, like subjective and objective resource value, as $T$. podisi is more generalist than T. urichi, P. guildinii eggs could have resulted of somewhat lesser value for the former parasitoid than for the latter.

Since for parasitoids there is a direct link between host encounter rate and the production of offspring, and considering that each parasitized host is killed, parasitoid searching efficiency and resource holding potential is also crucial to parasitoid-host population dynamics (Vet 2001). As most parasitoid hosts are utilized by more than one species of parasitoid, understanding the ecological factors that facilitate the coexistence of competing parasitoids and the factors that determine which species prevails is important both for basic ecology and for the applied science of biological control (De Moraes and Mescher 2005). Our results offer some insight into the potential interspecific competition between $T$. podisi and $T$. urichi, in terms of their host exploitation behavior. This information may contribute to manage such interactions to achieve sustainable management of pest populations through biological control, and to evaluate the compatibility of the use of multiple natural enemies for stink bugs control programs.

\section{ACKNOWLEDGMENTS}

This study was supported by Agencia Nacional de Promoción Científica y Tecnológica, grant PICT 2013-1322, and by the Programa de Incentivos a Docentes-Investigadores del Ministerio de Cultura y Educación de la Nación, grant 11/N777. M.C. Barakat was supported by a training scholarship of the Comisión de Investigaciones Científicas de la Provincia de Buenos Aires (CIC-GBA).

\section{AUTHOR CONTRIBUTIONS}

MFC contributed to the manuscript in terms of project design, data collection and analysis, results interpretation and paper writing. MCB contributed to the manuscript in terms of data collection, results interpretation and paper writing. GGL contributed to the manuscript in terms of data analysis, results interpretation and paper writing. SC contributed to the manuscript in terms of results interpretation and paper writing.

\section{REFERENCES}

BLASSIOLI MORAES MC, LAUMANN R, PAREJA M, SERENO FTPS, MICHEREFF MFF, BIRKETT MA, PICKETT JA AND BORGES M. 2009. Attraction of the stink bug egg parasitoid Telenomus podisi to defence signals from soybean activated by treatment with cisjasmone. Entomol Exp App 131: 178-188.

BLASSIOLI MORAES MC, LAUMANN R, SUJII ER, PIRES C AND BORGES M. 2005. Induced volatiles in soybean and pigeon pea plants artificially infested with the neotropical brown stink bug, Euchistus heros, and their 
effect on the egg parasitoid, Telenomus podisi. Entomol Exp App 115: 227-237.

BORGES M, COLAZZA S, RAMIREZ-LUCAS P, CHAUHAN KR, BLASSIOLI MORAES MC AND ALDRICH JR. 2003. Kairomonal effect of walking traces from Euschistus heros (Heteroptera: Pentatomidae) on two strains of Telenomus podisi (Hymenoptera: Scelionidae). Physiol Entomol 28: 349-355.

BORGES M, COSTA MLM, SUJII ER, CAVALCANTI MD, REDÍGOLO GF, RESCK IS AND VILELA EF. 1999. Semiochemical and physical stimuli involved in host recognition by Telenomus podisi (Hymenoptera: Scelionidae) toward Euschistus heros (Heteroptera: Pentatomidae). Physiol Entomol 24: 227-233.

BÜCHI L AND VUILLEUMIER S. 2014. Coexistence of specialist and generalist species is shaped by dispersal and environmental factors. Am Nat 183: 612-624.

CASTIGLIONI E, GIANI G, BINNEWIES C AND BENTANCUR O. 2008. Susceptibilidad de la chinche Piezodorus guildinii Westwood (Hemiptera: Pentatomidae) al insecticida Endosulfán. Agrociencia 12: 31-34.

CINGOLANI MF, GRECO NM AND LILJESTHRÖM GG. 2013. Multiparasitism of Piezodorus guildinii eggs by Telenomus podisi and Trissolcus urichi. BioControl 58: 37-44.

CINGOLANI MF, GRECO NM AND LILJESTHRÖM GG. 2014a. Egg parasitism of Piezodorus guildinii and Nezara viridula (Hemiptera: Pentatomidae) in soybean, alfalfa and red clover. Rev Fac Cienc Agrar, UNCuyo 46: 15-27.

CINGOLANI MF, GRECO NM AND LILJESTHRÖM GG. 2014b. Effect of Telenomus podisi, Trissolcus urichi, and Trissolcus basalis (Hymenoptera: Platygastridae) age on attack of Piezodorus guildinii (Hemiptera: Pentatomidae) eggs. Environ Entomol 43: 377-383.

COLAZZA S, AQUILA G, DE PASQUALE C, PERI E AND MILLAR J. 2007. The egg parasitoid Trissolcus basalis uses n-nonadecane, a cuticular hydrocarbon from its stink bug host Nezara viridula, to discriminate between female and male hosts. J Chem Ecol 33: 1405-1420.

COLAZZA S AND BIN F. 1995. Efficiency of Trissolcus basalis (Hymenoptera: Scelionidae) as an egg parasitoid of Nezara viridula (Heteroptera: Pentatomidae) in central Italy. Environ Entomol 24: 1703-1707.

COLAZZA S, CUSUMANO A, GIUDICE DL AND PERI E. 2014. Chemo-orientation responses in hymenopteran parasitoids induced by substrate-borne semiochemicals. BioControl 59: 1-17.

COLAZZA S, SALERNO G AND WAJNBERG E. 1999. Volatile and contact chemicals released by Nezara viridula (Heteroptera: Pentatomidae) have a kairomonal effect on the egg parasitoid Trissolcus basalis (Hymenoptera: Scelionidae). Biol Control 16: 310-317.
CONTI E AND COLAZZA S. 2012. Chemical ecology of egg parasitoids associated with true bugs. Psyche 2012, 11 p.

CONTI E, SALERMO G, BIN F AND VINSON SB. 2004. The role of host semiochemicals in parasitoid specificity: a case study with Trissolcus brochymenae and Trissolcus simoni on pentatomid bugs. Biol Control 29: 435-444.

CONTI E, SALERNO G, BIN F, WILLIAMS HJ AND VINSON SB. 2003. Chemical cues from Murgantia histrionica eliciting host location and recognition in the egg parasitoid Trissolcus brochymenae. J Chem Ecol 29: 115-130.

CORRÊA-FERREIRA BS. 1993. Utilização do parasitóide Trissolcus basalis (Wollaston) no controle de percevejos da soja, Londrina: Embrapa, 40 p.

CORRÊA-FERREIRA BS. 2008. Trissolcus basalis para o controle de percevejos da soja. In: Parra JRP, Botelho PSM, Corrêa-Ferreira BS and Bento JMS (Eds), Controle biológico no Brasil - parasitóides e predadores, Piracicaba: Ed. Manole, p. 449-471.

CORREAA-FERREIRA BS AND AZEVEDO J. 2002. Soybean seed damage by different species of stink bugs. Agric Forest Entomol 4: 145-150.

CUSUMANO A, PERI E, AMODEO V, MCNEIL JN AND COLAZZA S. 2013. Intraguild interactions between egg parasitoids: Window of opportunity and fitness costs for a facultative hyperparasitoid. PLoS ONE, 8: e64768.

CUSUMANO A, PERI E AND COLAZZA S. 2016. Interspecific competition/facilitation among insect parasitoids. Curr Opin Insect Sci 14: 12-16.

CUSUMANO A, PERI E, VINSON SB AND COLAZZA S. 2011. Intraguild interactions between two egg parasitoids exploring host patches. BioControl 56: 173-184.

CUSUMANO A, PERI E, VINSON SB AND COLAZZA S. 2012a. Interspecific extrinsic and intrinsic competitive interactions in egg parasitoids. BioControl 57: 719-734.

CUSUMANO A, PERI E, VINSON SB AND COLAZZA S. 2012b. The ovipositing female of Ooencyrtus telenomicida relies on physiological mechanisms to mediate intrinsic competition with Trissolcus basalis. Entomologia Entomol Exp App 143: 155-163.

DE MORAES CM AND MESCHER MC. 2005. Intrinsic competition between larval parasitoids with different degrees of host specificity. Ecol Entomol 30: 564-570.

DEPIERI FA AND PANIZZI AR. 2011. Duration of feeding and superficial and in-depth damage to soybean seed by selected species of stink bugs (Heteroptera: Pentatomidae). Neotrop Entomol 40: 197-203.

ENQUIST M AND LEIMAR O. 1987. Evolution of fighting behavior: the effect of variation in resource value. $\mathrm{J}$ Theor Biol 127: 187-206.

ENQUIST M AND LEIMAR O. 1990. The evolution of fatal fighting. Anim Behav 39: 1-9. 
FATOUROS NE, CUSUMANO A, DANCHIN EG AND COLAZZA S. 2016. Prospects of herbivore egg-killing plant defenses for sustainable crop protection. Ecol Evol 6: 6906-6918.

FATOUROS NE, DICKE M, MUMM R, MEINERS T AND HILKER M. 2008. Foraging behavior of egg parasitoids exploiting chemical information. Behav Ecol 19: 677-689.

FIELD SA. 1998. Patch exploitation, patch-leaving and preemptive patch defense in the parasitoid wasp Tirssolcus basalis (Insecta: Scelionidae). Ethology 104: 323-338.

FIELD SA AND CALBERT G. 1998. Patch defence in the egg parasitoid Trissolcus basalis: when to begin fighting? Behaviour 135: 629-642.

FIELD SA AND CALBERT G. 1999. Don't count your eggs before they're parasitized: contest resolution and the tradeoffs during patch defense in a parasitoid wasp. Behavl Ecol 10: $122-127$.

FIELD SA, CALBERT G AND KELLER MA. 1998. Patch defence in the egg parasitoid Trissolcus basalis: the timestructure of pairwise contests, and the "waiting game". Ethology 104: 821-840.

GAMUNDI JC AND SOSA MA. 2008. Caracterización de daños de chinches en soja y criterios para la toma de decisiones de manejo. In: Trumper EV and Edelstein JD (Eds), Chinches fitófagas en soja. Revisión y avances en el estudio de su ecología y manejo, Manfredi: Ediciones INTA, p. 129-148.

GODFRAY HCJ, HASSELL MP AND HOLT RD. 1994. The population dynamic consequences of phenological asynchrony between parasitoids and their hosts. J Anim Ecol 63: 1-10.

GOUBAULT M, CORTESERO AM, POINSOT D, WAJNBERG E AND BOIVIN G. 2007. Does host value influence female aggressiveness, contest outcome and fitness gain in parasitoids? Ethology 113: 334-343.

HAMMERSTEIN P. 1981. The role of asymmetries in animal contests. Anim Behav 29: 193-205.

HUGHES RN. 1979. Optimal diets under the energy maximization premise: the effects of recognition time and learning. Am Nat 113: 209-221.

KIVAN M AND KILIÇ N. 2002. Host preference: parasitism, emergence and development of Trissolcus semistriatus (Hym., Scelionidae) in various host eggs. J Appl Entomol 126: 395-399.

LILJESTHRÖM GG AND AVALOS S. 2015. Nuevas asociaciones entre Phasiinae (Diptera: Tachinidae) y Pentatomidae (Hemiptera: Heteroptera) fitófagos en la pampa ondulada (Argentina) y descripción del macho de Dallasimyia bosqi Blanchard. Rev Soc Entomol Arg 74: 145-152.

LILJESTHRÖM GG AND CAMEÁN P. 1992. Parasitismo de una población de la "chinche verde" Nezara viridula (L.) (Hemiptera: Pentatomidae) por el parasitoide oófago
Trissolcus basalis (Woll.) (Hymenoptera: Scelionidae). Rev Fac Agron, La Plata 68: 71-76.

LO GIUDICE D, PERI E, LO BUE M AND COLAZZA S. 2010. Plant surfaces of vegetable crops mediate interactions between chemical footprints of true bugs and their egg parasitoids. Commun Integr Biol 3: 70-74.

MARGARÍA CB. 2008. Microhimenópteros parasitoides de huevos de insectos y arañas. Estudio sistemático y biológico de potenciales agentes de control integrado de plagas. PhD dissertation, Facultad de Ciencias Naturales y Museo (UNLP), La Plata, Argentina.

MAYNARD SMITH J. 1974. The theory of games and the evolution of animal conflicts. J Theor Biol 47: 209-221.

MAYNARD SMITH J AND PARKER GA. 1976. The logic of asymmetric contests. Anim Behav 24: 159-175.

NELSON JM AND ROITBERG BD. 1995. Flexible patch time allocation by the leafminer parasitoid, Opius dimidiatus. Ecol Entomol 20: 245-252.

PACHECO DJP AND CORRÊA-FERREIRA BS. 1998. Potencial reprodutivo e longevidade do parasitóide Telenomus podisi Ashmead, em ovos de diferentes espécies de percevejos. An Soc Entomol Bras 27: 585-591.

PARKER GA. 1974. Assessment strategy and the evolution of animal conflicts. J Theor Biol 47: 223-243.

PERI E, CUSUMANO A, AGRÓ A AND COLAZZA S. 2011. Behavioral response of the egg parasitoid Ooencyrtus telenomicida to host-related chemical cues in a tritrophic perspective. BioControl 56: 163-171.

PERI E, CUSUMANO A, AMODEO V, WAJNBERG E AND COLAZZA S. 2014. Intraguild interactions between two egg parasitoids of a true bug in semi-field and field conditions. PLoS ONE 9: e99876.

PERI E, FRATI F, SALERNO G, CONTI E AND COLAZZA S. 2013. Host chemical footprints induce host sex discrimination ability in egg parasitoids. PLoS ONE 8: e79054.

PERI E, SOLE MA, WAJNBERG E AND COLAZZA S. 2006. Effect of host kairomones and oviposition experience on the arrestment behavior of an egg parasitoid. J Exp Biol 209: 3629-3635.

POWELL JE AND SHEPARD BM. 1982. Biology of Australian and United States strains of Trissolcus basalis, a parasitoid of the green vegetable bug Nezara viridula. Austral Ecol 7: 181-186.

POWELL W AND WRIGHT AF. 1992. The influence of host food plants on host recognition by four aphidiine parasitoids (Hymenoptera: Braconidae). Bull Entomol Res 81: 449-453.

R CORE TEAM. 2014. R: A language and environment for statistical computing. Vienna, R Foundation for Statistical Computing. URL http://www.R-project.org/. 
RIDER DA. 2015. Hymenoptera parasitoid records. Available at http:/www.ndsu.nodak.edu/ndsu/rider/Pentatomoidea/ Natural_Enemies/parasitoid_Hymen_Pent.htm

SALERNO G, FRATI F, CONTI E, DE PASQUALE C, PERI E AND COLAZZA S. 2009. A finely tuned strategy adopted by an egg parasitoid to exploit chemical traces from host adults. J Exp Biol 212: 1825-1831.

STEIDLE JLM AND VAN LOON JJA. 2003. Dietary specialization and infochemical use in carnivorous arthropods: testing a concept. Entomol Exp Appl 108: 133-148.

STEPHENS DW AND KREBS JR. 1986. Foraging theory, Princeton: Princeton University Press, 247 p.

SUJII ER, COSTA MLM, PIRES CS, COLAZZA S AND BORGES M. 2002. Inter- and intra-guild interactions in egg parasitoid species of the soybean stink bug complex. Pesqui Agropecu Bras 37: 1541-1549.

TEMPLE J. 2011. Redbanded stink bug, Piezodorus guildinii (Westwood): pest status, control strategies, and management in Louisiana soybean. Ph.D. dissertation, Louisiana State University and Agricultural and Mechanical College.

TEMPLE JH, DAVIS JA, MICINSKI S, HARDKE JT, PRICE P AND LEONARD BR. 2013. Species composition and seasonal abundance of stink bugs (Hemiptera: Pentatomidae) in Louisiana soybean. Environ Entomol 42: 648-657.

VET LEM. 2001. Parasitoid searching efficiency links behaviour to population processes. Appl Entomol Zool 36: 399-408.

ZAR JH. 1996. Biostatistical Analysis, New Jersey: Prentice Hall, 662 p.

ZWÖLFER H. 1971. The structure and effect of parasite complexes attacking phytophagous host insects. In: Den Boer PJ and Gradwell GR (Eds), Dynamics of numbers in populations: Proceedings of the advanced study institute on "Dynamics of numbers in populations", Wageningen: Center for Agricultural Publishing and Documentation, $\mathrm{p}$. 405-418. 